\title{
Research on Cultural Supply Chain Integration and Invocation
}

\author{
Qian Zhang \\ School of Business, Huaqiao University, Quanzhou, China \\ Email: zhangyl@hqu.edu.cn
}

Received 18 May 2014; revised 21 June 2014; accepted 11 July 2014

Copyright (C) 2014 by author and Scientific Research Publishing Inc.

This work is licensed under the Creative Commons Attribution International License (CC BY). http://creativecommons.org/licenses/by/4.0/

(c) (i) Open Access

\begin{abstract}
Supply chain management is an integrated management method for solving these effective problems which were integrated in existing resources with the overall competitiveness and theirs effects. The supply chain integration and innovation models are proposed with the development and current situation for these global Chinese businessmen. The supply chain integration is given in order to optimize for the culture of Chinese business management. It is established that these practice network platform for supply chain management are presented service for Chinese businessmen. And they realize these integration innovation in the logistics system, financial system, Chinese business culture system, production manufacturing system, and customer service system. These suggestions are provided for the development of Chinese business culture in supply chain theory. These further forward Chinese culture are given some fruitful reference for constructing a new development for the world Chinese businessmen's culture management.
\end{abstract}

\section{Keywords}

Culture of Chinese Business, Supply Chain Integration, Innovation Model, Optimization Scheduling

\section{Analysis on the Status of the Global Chinese Business Culture Developing}

Supply chain management is an integrated management method, which is an effective means which integrates existing resources, enhances overall competitiveness, and establishes brand effect. With the development of economics and society, it is a hot topic on Chinese business. This research is emphasized on this topic which is paid more attention by the Chinese businessman group. They are the persons who had nationality in China or had Chinese blood in their body. And those businessmen trend to increase actively in international business environment, including those people from Hong Kong and Macao, Tai Wan businessmen, and specialized in business activities overall the world. Those Chinese businessmen were working on the international economy 
which is considered outside the China in the paper.

\subsection{The world Chinese Businessmen's Status}

Along with the development of economical globalization and Chinese business's, recently, there was a transformation in the Chinese business, not only transformed from vocation, but also the management already had transformed from extensive to modernization; but overall, considered the number, the Chinese business group had the small traders at most. Traditional Chinese economy born after the overseas Chinese migrated to abroad. The overseas Chinese tried to live a life and lacked of technology, so they had to have the simplest works, which were called as the three swords, scissors, cook chopper, razor [1]. As the time went by, the second generation Chinese businessmen and new immigrants had broken out. The Chinese businessmen transformed from single catering industry; the clothing industry, and progressively set foot in external trade, electron, hi-technology, and had engaged in the finance, estate, new hi-technology, lawyer, accountant, etc. But generally speaking, most Chinese businessmen of the global occupied retail industry which was small capital, low technologic, week compete and bad economic benefits, and the food service industry, the Chinese medicine acupuncture [2]. The Chinese food service industry was widespread, just in America; there were more than 50,000 Chinese restaurants, and near 300,000 Chinese employees. The Chinese goods were sold through the world, resulted in the small shop became a general occupation [3].

\subsection{New Circumstances Made a Great Influence}

Along with speeding up the step of Chinese enterprises "goes out”, new continental Chinese businessmen rapidly growth became as the feature and bright point of global economy [4]. New Chinese businessmen, the new oversea Chinese, mostly meant the Chinese people immigrated oversea for private after Reform and Openness, included the peopled had immigrated oversea by all means for the 30 years, and the children who lived with them and born over sea [5]. It was called as New Immigrant. New oversea Chinese was different with New Chinese in whether adding other nationality or not. For 30 years of Reform and Openness, New oversea Chinese and new Chinese who immigrated oversea, had advanced the great change of global Chinese business structure. In pace with economy globalization development, the new Chinese business group which consisted of new oversea Chinese and new Chinese, played an important role in improving the economic exchanges and cooperation between residence country and China [6].

\subsection{New Changes of Global Chinese Business Structure}

This great change, included two sides, one was the spread of Chinese became more extensive, the others was global Chinese business industry had been broadened. Traditional Chinese businessmen gathered in Southeast Asia. But new oversea Chinese and new Chinese grew their enterprises in Northern America, Western Europe, Australia, Japan, and other developed countries. There were many oversea Chinese in Northern America new technological area, Chinese businessmen in Europe mostly came from Zhejiang province, and the Korea nationality in northern east three province immigrated to Korea. From the quality, new oversea Chinese and new Chinese fastened on America, Canada, Japan, Australia, New Zealand, France, English, Italy, Spanish, Germany, Russia and other countries or areas. The global Chinese business industry had a marked change. There was a most marked change in occupational structure of the new oversea Chinese and new Chinese, that the percent of technological occupation constantly advanced, and the number people occupied industry and commerce distinctly increased [7] [8].

\subsection{The Important Power Enlivened on the World Economy Stage}

It performed in three aspects: Firstly, it enlivened local economy; secondly, it promoted the contact among the world economy; thirdly, it improved economic exchange between residence country and China. New Chinese businessmen promoted the development of world economy.

New oversea Chinese and new Chinese entered, to change the economic structure of Chinatown, and promote the appearance of industry chain centered on Chinatown. Along with the immigrant of new oversea Chinese and new Chinese, as the process and sales center Chinatown was, the productivity expended following the raise of goods consumption. Chinatown gradually became the supplement center of the new oversea Chinese and new 
Chinese articles for daily use and the civilization requirement, and even the process center of oriental products in the face of the whole social [9] [10].

\section{Influence Power Analysis of Chinese Business in the World}

\subsection{Chinese Business Regarded to Themselves}

Generally speaking, most Chinese businessmen in the world still engaged in retail trade, catering service, Chinese medicine acupuncture and others occupations which were small asset, low technology, weak competitive power and bad economic benefit. Chinese catering industry was still the most universal occupation for Chinese businessmen at the present [11].

\subsection{The World Regarded to Chinese Business}

Chinese business was accused of anti-dumping frequently as people had a meal. Specially many countries did not admit that Chinese Mainland was perfect competition market economy and it had maximum anti-dumping complain continuously for more than ten years after it opened its market to the world, for these two aspects, we all felt the unkindness the world faced with Chinese businessmen, specially Chinese Mainland businessmen [12].

\subsection{Chinese Business Regarded to the World}

Chinese business acted in the world for more than ten years, several decades, even several generations of time, made an assignable contribution to economy of the world. Recently, Chinese businessmen took hi-technology to West Asia, Africa and other countries [13]. Planting vegetables in the desert, brought the fresh power to native people's lives, moistened the people's hearts, developed native economy and market: Brought advanced technology to the places whose technology stayed savagery, mended native faming methods, improved native people's living condition, developed native productivity, and so on. However, some situations did not agree with our minds. For example, the farmers went to Africa as experts. The planting technology is introduced to Zambia by the farmers in Hebei province. These original planting concepts are accepted for enhancing economic development of Zambia. However, the land would change into tragedy: Land fertility descended along with framing dates increasing, and chemical fertility, pesticide invaded this clean land; Foodstuff, vegetable chain became improving, and market grew perfect, wealth accumulation raised, resulted in the entry of modern industry, parts of rural areas separated and changed into core cities, and disparity between poor and wealth expanded, the original purity world disappeared; the new object entered constantly, Mortgage Burden, Car Slave, Disease Mortgagor came out... Another example, the Middle East desert became kaleyard, using the poor water to plant vegetable was unkind, and whether it was good for harmony between man and nature or not that people plant vegetables in dry and torrid desert, it could not avoid natural punishment if people applied natural rule wrongly, was there more scientific development concept and models... Again for instance, Chinese went to Brazil as landowners, through establishing company and having the right of permanent residence, bought a lot of land in Brazil, invested productivity, whether consider to the human benefit and welfare that people protected the environment of Brazil.

When Chinese business took productivity and labor service to the world, whether consider to leave the happiness in the land they work. It was not scientific and perfect. First, left permanent pity and indelible pain to their country, do not think themselves, do not make response to themselves and so on. What was worse, they went others countries to speak, made benefit in heart but made the harm, bad business... Their country's cheap labor force was bled by them, and wants to bled others countries; made so many harmful goods from the land, commissariat, vegetables, foodstuff, and made that to others; polluted the environment, even could not respond to their ancestors and posterities, now they polluted others... Sometimes, sweaty heart only was their minds. They felt they were doing good jobs, making benefits, but actually they were doing bad jobs or even worse. In 19th century, most oversea Chinese had hard labor work. Before 1970s, the first ancestor of oversea Chinese, most devoted into traditional handicraft industry and service industry; above the workers, the oversea Chinese also included students abroad, professional immigrants and invest immigrants, their jobs involved wholesale, retail, import and export trade, supermarket, finance and real estate, they gradually established new markets, their works became diversification; otherwise, some high-knowledge oversea Chinese and high-asset oversea Chinese in southeast countries and their children in China, built high-technology company in America, Canada, 
England. These new Chinese business high-technology companies had a great development in 20 years, sighed the new tendency of oversea Chinese business.

New oversea Chinese business broadened living country's scope and depth of service industry. The coming of new oversea Chinese, not only made the traditional garment factory, Chinese restaurant, grocery store and Chinese food supermarket more prosperous, but also grew some relevant industry and service, for example, immigrant service agent, Chinese style wedding company, remittance company, acupuncture therapy room, real estate agent. When the new oversea Chinese poor energy came into oversea Chinese business, they made a contribution to living country. In the side of improving relationship between economy and trade, new oversea Chinese business devoted in industry and business, that was a good example.

Many Chinese immigrant import and export companies, wholesales and trade markets grew in Europe. Paris had 3113 oversea Chinese businessmen. 40.5\% of them dealt with business activities formed Chinese trade-andwholesale area which had more than 3000 storefronts. In Italy, Chinese factories which based on thousands of family workshops, mainly engaged in garment, leather goods production and sales, and Chinatown formed the biggest trade center of Chinese in European. Many Chinese living in Russia were individual traders. Most engaged in international traffic and other folk trade, clothing sales, computer and accessories, communication equipments, software and other Chinese goods. Large business company and trade center which engaged by Chinese business, became one part of local economy. Some even became an international business center which covered several countries and regions surrounded it, promoting the world economy [14].

\subsection{The Bridge between China and the World to Exchange Economy}

New overseas Chinese lived in overseas, but the majority of them lived in China, had studied and worked there, had well know of it, and naturally became an important channel for private communication. In Japan, more than 3000 companies were created by a new generation of Chinese merchants, mostly were trading companies. Moreover, the new Chinese understood the national conditions and local cultural customs, the way of thinking, were familiar with the business model and operation character, so many people provided consulting service for the economic and trading cooperation between foreign enterprises and China, became the consultant for the living country enterprise to develop Chinese market, even organized enterprises to invest in China, exhibited in the investment consulting, financial services and other fields.

\subsection{The Rapid Growth in Net of Chinese Direct Investment to Foreign}

A large number of the strength Chinese enterprises, such as Lenovo Group, Haier Group, Huawei Group, ZTE Group, and so on, developed international operation, distributed business in the world, had made a positive progress. A large number of Chinese entrepreneurs moved to the world, became huge new oversea Chinese merchants strength.

Chinese private enterprises built "China City" in the world. It was also an important manifestation of the rise of new Chinese business. In 1998, the merchant of Wenzhou established the first China City in Brazil, St Paul. Since then, Wenzhou merchants established ten more China City in many countries, such as Cameroon, Russia, Holland, United Arab Emirates, the United States, Britain, Mongolia, Chile and Finland, and other countries. The overseas Chinese business had a good development in China, and promoted its overseas business.

The overseas merchants earn much money, thanked to invest in mainland of China. The rapid development of Chinese economy provided the unknown development opportunities for global overseas Chinese business. Let us see a group data of early investment in mainland of China: according the Ministry of Commerce statistics, in 2007, China had approved the establishment of 34,419 foreign investment enterprises, actually use foreign capital about $\$ 616.74$ billion, 13.66\% growth on year. Hong Kong, the British Virgin Islands, South Korea ranked the top ten, invested in China, and a large number of Chinese merchants got together there. Chinese enterprises earned much money by investing in the mainland, grew the enterprises asset. In addition to the direct investment benefit, "made in China" sold worldwide, brought a new business opportunity for the local Chinese merchants. A lot of goods "made in China" marketed the world by the Chinese business network, and took a big benefit to the Chinese merchants, promoted the further development of Chinese business groups. In addition, the development of China and the international status constantly improvement, enhanced the self-confidence of overseas Chinese, and the identity of national culture, provided a strong brace to do economic activities for them. 


\subsection{Steadied the New Industry and Exhibited Well}

The development of Chinese businessmen were inseparable with the living countries, more and more Chinese merchant regarded himself as a member of living country, aided by the local law, made efforts to integrate into the local community, and became an important part of the local economy. The development of Chinese business continuously improved the well-being of local people, gained local society and public recognition day by day.

\subsection{The Touchstone of the Financial Crisis}

The financial crisis began in 2008 damaged the global, also impacted overseas Chinese enterprises. The traditional and survival industries, such as trading, catering, manufacturing and other industries, had a hard supporting in the tide of crisis; Chinese business elites faced employment and entrepreneurship dilemma, wandered in the future between instance and abandon. Among them, large listed Chinese enterprises assets had shrunk significantly as the stock market felling. The Chinese business assets in 2008 reduced 1/3 than in 2007, reduced to $\$ 1.2$ trillion. Real estate depreciation and currency turmoil leaded overseas Chinese enterprises assets to reduce in North America, Europe. The world financial crisis was destroying economy, came with the world economic recession, tasted the world overseas Chinese merchants over five continents. In 2009, the world overseas Chinese enterprises would face enormous difficulties and challenges. However, we should find that, nearly 48,000,000 overseas Chinese merchants in the world, were still increasing, provided deep soil for Chinese enterprise to expand market, to strength. After 30 years of reform and opening up, China had accumulated enormous society wealth, laid a solid economic foundation, also formed a very potentially domestic market; in 2008, China's GDP reached more than 30 trillion RMB, 9\% growth over the previous year. This was no doubt that it provided a wider stage of the development of world Chinese enterprise.

\section{Effect of the Chinese Business Cultural Supply Chain in the Development of the World's Economy}

The good prospect of world Chinese business: Get their want that "helped themselves and the world". Chinese merchants wanted to benefit themselves and the world, and that was near. This paper intended to build Chinese business sharing supply chain management cultural platform, so as to service better for the global economy, spread the Chinese culture to the world, strode to promote foreign relations.

Through the establishment of the fourth party supply chain management information platform: integrated Chinese merchants resource at hands, explored the statue of the Chinese merchants, explored the new development means of the Chinese merchants, improved service ability of the Chinese merchants, wrote the new chapter of Chinese business history... What resources did Chinese merchants provide? The huge economic entity provided a strong backing for the Chinese merchants to voyage abroad; the world advanced technology rapidly updated, promoted the Chinese business in the world market; the outstanding character of the Chinese nation was the solid foundation for Chinese merchants standing in the world economic stage.

\section{Chinese Business Culture in Supply Chain Integration and Innovation Modle}

The innovation mode mainly denoted to the forth information source conformity and integration. In other words, via technological means, advanced management and scientific technology, afforded high quality products and service, we did not hurt people's health, natural environment, descendants' bliss to make cheap and fine anymore, we devoted convincing products and services. We had a team which mastered international regulations, legitimated interests of Chinese businessmen in the stage of the world economy. In order to force down "malicious behavior to anti-dumping”, Chinese merchants could even build unity nominally, united front substantially, shared weal and woe, hand in hand. We could create a efficient logistics system to service the world Chinese businessmen, to make the first class products and top-notch service not discount. Outputting the talent and technology was even more important. It must be good things; must be able to create a happy and perfect; must earn the glory and splendor; and could be output. By then, the world Chinese merchants established Chinese business culture, and the love wind would warm the human heart.

Via constructing a culture supply chain management and practice internet platform to service Chinese merchants, the manage and practice of logistics system, finance system, Chinese business culture system, 
product name system, customer service system effectively came true.

1) General idea

Established Chinese business culture supply chain management and practice platform as carrier; signed building "logistics cloud" information platform as the core hub; treated logistics industry chain management service as object; integrated and collocated logistics industry chain as measure; improved logistics efficiency; reduced logistics cost as root; promoted regional economy development; built harmonious society as target.

2) Objective

Chinese business culture supply chain management and practice platform mainly included modern logistics cloud information platform and Chinese business logistics service headquarter. Established Managed centre area duly by development.

\section{1. "The Logistics Cloud" Information Platform}

Platform construction imagine: using cloud compute technology, integrated the service resources of logistics industry chain, constructed modern logistics cloud public service platform to provide one-step service resources allocation to enterprises in logistics industry chain.

1) Platform service content: by the means of cloud compute technology, virtually integrated and distributed logistics resources, offered logistics public information exchanged services, logistics resources allocation services, logistics operation, transaction and allocation services, logistics industry chain enterprise information services; achieved information of logistics industry chain operation, management and service.

2) Platform service object: Faced the industry chain service of related business, with the third party logistics service as the main body; extended the first party, the second party and service of industry chain supporting facilitator; achieved the fourth party service of logistics industry chain management service.

3) Distribution function of the platform: played pivotal function of platform fully; attracted the agglomeration of domestic and foreign third logistics providers; formatted the distribution center of logistics providers; attracted the gathering of the first party and the second party enterprises; combined the virtual with the physical; formed products distribution center, warehousing center, trading center; attracted the gathering of supporting services providers of logistics industry; formed the supporting service center and consulting center of logistics.

4) Integration resources effect of platform: integrated related enterprises resources, logistics requirement resources, product services resources and markets information resources of logistics industrial chain; formed logistics cloud resources database, via the exchange of information and date; realized to agglomerate and scientifically configure virtual resource; realized the solid service and rapid response services and other general service; formed the data center of logistics resource, information exchange center and resource collocation center; applied the payment function of platform; played the siphon effect of platform; formed the trading payment center of logistics service and capital accumulation center.

\subsection{Chinese Business Logistics Service Headquarters Base}

The base took the headquarters building as the main body, formed perfect Chinese business logistics service headquarters base. Construction scale accorded to development goal. The main function of Chinese business logistics service headquarters base: included operation center of modern logistics cloud information platform, headquarters center of the third logistics enterprise, logistics headquarters center of the first and the second enterprise, headquarters center of logistics service enterprise, logistics public service center, cultural exhibition and trading center.

1) Information platform operation center provided operation site and installation to modern logistics cloud information platform.

2) The third party logistics enterprise headquarters center provided the headquarters base to third party logistics enterprises; introduced domestic and foreign well-known third party logistics enterprises; formed logistics distribution center and gathering center.

3) The first party, the second party logistics business headquarters center provided the window base for the manufacturing enterprises, trading enterprises which was the enterprise between the first party and the second party logistics.

4) Logistics service enterprise headquarters center provided a window base for enterprise of logistics industry chain supporting service; attracted logistics supporting service business; established perfect logistics supporting 
service system.

5) Logistics public service security center provided fully range public services for enterprises and service providers in logistics industry chain. Security center provided office space and infrastructure, presentation and negotiation venues, accommodation and catering establishments and senior management personal apartment and other logistics security synthesized service.

6) Cultural exhibition and trade center established cultural supply chain conference center; provided the service of various kinds of conferences activities for logistics industry development; established commodity exhibition center; provided exhibition window for each owner; organized various goods and services to exhibit; established commodity trading center; played all advantages of commodity and information agglomeration; used the means of electric business; established commodity online exhibition trading market; promoted the circulation of goods and the development of logistics.

7) Talent research center. Enterprises would strengthen cooperation with universities, set up logistics industry research center, logistics talent introduction center and training center. Through the cooperation and communion, formatted agglomeration center and exchange center of talents, via organization and training, became the training base of logistics talents.

8) The new economic organization construction base, in the base of enterprises organization establishment of Chinese business logistics service headquarters base, strengthened the building of party organization, trade unions, women's federations, Youth League and charitable institution, the enterprise in enterprise organization; researched the means of new economic organization establishment for cultural supply chain management industry; strengthened the leadership of the party and undertook the social responsibility. Looked the supply chain information service platform as a stock exchange, we were not any intermediary institutions, such as the securities companies, investment companies, fund companies and other financial intermediaries.

\subsection{Successful Case of Information Platform}

“Taobao model” was the platform model. The value of Taobao model regarded as the value of network platform. Its sociality, regarded as the social value of network platform enterprise. Taobao model had the "three in one", created social value. Electronic commerce included information flow, capital flow and logistics. Here, we had social value from the three aspects of Taobao model. Firstly, noised about the information, broke the commercial unspoken rule. Secondly, optimized the capital flow, enhanced the fund efficiency of the enterprise. Thirdly, promoted each other and rapidly grew in logistics area; Taobao model strategy. Lastly, Taobao model strategy was a concept of gathering parts into a whole, and breaking up the whole into parts. Taobao provided the network distribution platform for the merchants, gathered merchant's resources to consumers, helped to save the consumers' cost and made the shopping of consumer been convenience. Convenient and cheap/low cost were the attractive advantages of $\mathrm{C} 2 \mathrm{C}$ online shopping compared with the traditional shopping.

\section{Conclusion}

Information service system also related with the state department, conduced to manage the world Chinese business normally, to become the world business alliance, aimed to build a public platform with cooperation, communion and investment for all the Chinese businessmen. Via this platform, we talked about business experience, devoted to public welfare undertaking, and looked for partners to business. Sincerely we hoped that all the Chinese businessmen joined us. We made joint efforts to make our companies and brands better and stronger. And the world would accept Chinese business and respect Chinese business.

\section{Acknowledgements}

This paper was supported in part by Program for New Century Excellent Talents in University under grant number NCET-10-0118, in part by 2013 year Ministry of Culture art of Scientific Research Project under grant number 13DH50, in part by National Natural Science Foundation of China under grant number 71040009.

\section{References}

[1] Grillo and Guo, Z.J. (2008) The Report of Chinese Business Development. China News Service, Peking.

[2] (2003) Honor, Disgrace and Predicament of Chinese Business in the World. www.chinareviewnews.com 
[3] Qiu, J. (2011) Annual Report on Overseas Chinese Study. Social Sciences Academic Press, Peking.

[4] (2006) The World Chinese Entrepreneurs Convention. http://www.sina.com.cn

[5] (2009) The Tenth World Chinese Entrepreneurs Convention Jin Entrepreneurs Delegaton, China Commodity Exhibition, Chinese Business Industry. www.wsxm.net

[6] Shu, H. (2005) Integration Logistics. Science Press, Peking. www.sciencep.com

[7] Wei, Z.C. (2013) On Logistics Information Platform Construction and Development of Cloud Computing. Guide to Business, 204.

[8] Pu, Q.F. and Qian, Y.Y. (2010) Development of the Retailer-Centered Supply Chain Information Sharing Platform. Logistics Technology, 167-169.

[9] Hu, Y.F. and Huang, S.Q. (2009) Supply Chain Finance: Background, Innovation and Concept. Research on Financial and Economic Issues, 76-82.

[10] Dai, D.D. (2004) The Unique Value of Traditional Chinese Business Culture in Modern Management. Journal of Northeastern University, 1, 42-45.

[11] Exploration of Cultural Property Transactions in Financial Standards [EB/OL]. http://news.ifeng.com/gundong/detail2012/03/03/129316660.shtml

[12] Fan, Z.G. and Zhang, X.L. (2010) Cluster-Based Supply Chain Study of Cultural Creative Industry Coupled EBusiness and Information System Security (EBISS).

[13] Yu, P. and Fu, C.W. (2013) Annual Report on China’s Cultural Innovation. Social Sciences Academic Press, Peking.

[14] Li, X.J. and Zhang, Q. (2013) Research on Definition and Models of Culture Supply Chain. Journal of Minzu University of China, 2, 16-22. 
Scientific Research Publishing (SCIRP) is one of the largest Open Access journal publishers. It is currently publishing more than 200 open access, online, peer-reviewed journals covering a wide range of academic disciplines. SCIRP serves the worldwide academic communities and contributes to the progress and application of science with its publication.

Other selected journals from SCIRP are listed as below. Submit your manuscript to us via either submit@scirp.org or Online Submission Portal.
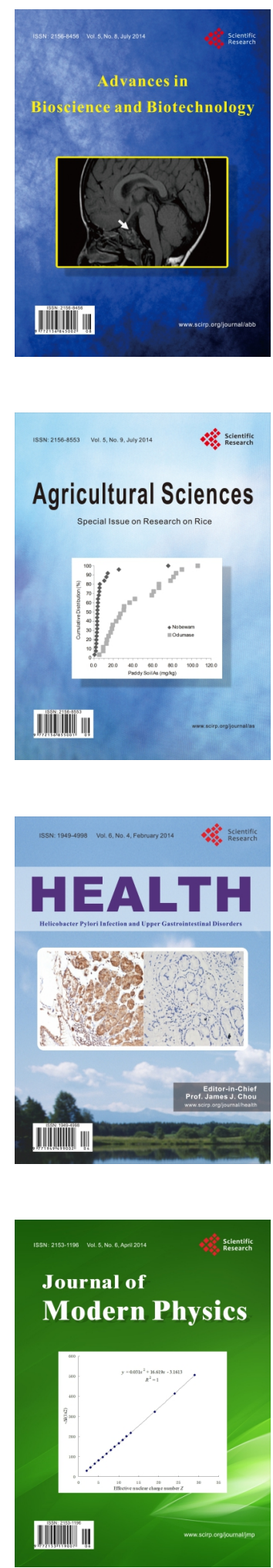
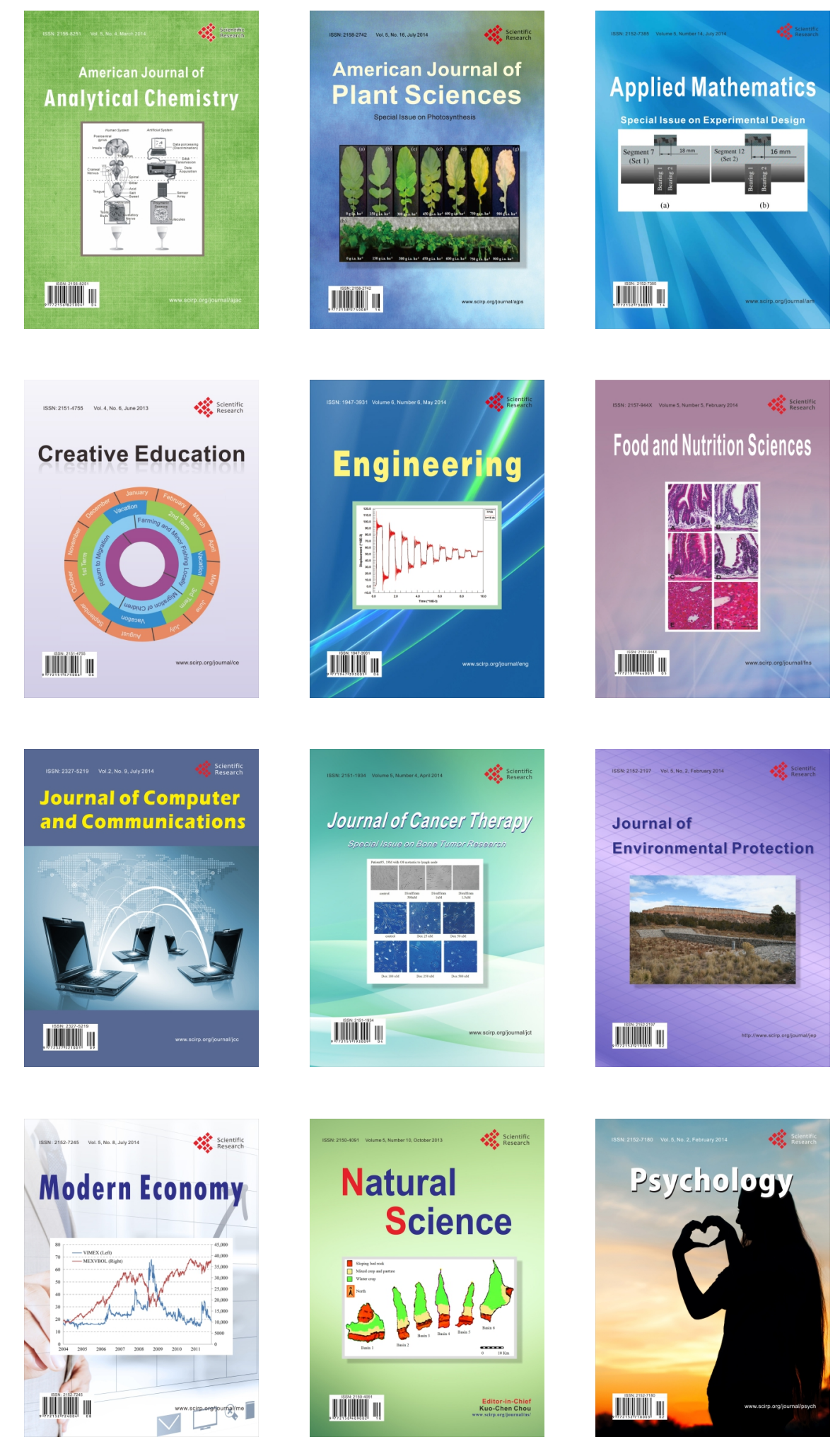